DOI:10.31696/2072-8271-2020-3-4-49-145-153

\title{
The Specificity of Myanmar's Relations with China in the Beginning of the XXI Century (2001-2010)
}

Wai Yan Phyo Naing

PhD Student, HSE University, Russia, Moscow, Myanmar, ywai@hse.ru, https://orcid.org/0000-0001-8358-1258

Abstract: The article gives a critical insight into Myanmar's relations with China between 2000 and 2010. Starting from an analysis of the political vector of these relations, the article explores the specificity of economic cooperation, including China's investment in Myanmar's infrastructure projects to finally turn to the grass-root perception of China's policy in Myanmar. In the author's opinion, China's influence in Myanmar should not be overestimated owing to a gap between official declarations of the Tatmadaw regime and the grassroot-level Sinophobia premised upon perceptions that Chinese business practices were inefficient, corrupted, and were implemented without due regard to the interests of local citizens.

Keywords: Myanmar-China relations, political contacts, bilateral trade, infrastructure projects, local perceptions, Sinophobia

\section{Особенности отношений Мьянмы с Китаем в начале XXI века (2001-2010 гг.)}

\section{Вей Ян Пьё Найнг}

аспирант НИУ ВШЭ, Россия, Москва, Мьянма, уwai@hse.ru https://orcid.org/0000-0001-8358-1258

Аннотация: В статье проводится критическое осмысление отношений Мьянмы с Китаем между 2000 и 2010 гг. Проанализировав политическое измерение этих отношений, автор статьи выявляет специфику экономического сотрудничества сторон, включая инвестиции Китая в инфраструктурные проекты Мьянмы, переходя к рассмотрению восприятия китайской политики в Мьянме на уровне простых граждан. С точки зрения автора, влияние Китая в Мьянме не следует преувеличивать по причине несоответствия официальных деклараций военного режима Мьянмы и антикитайских настроений на низовом уровне. Согласно последним, китайские деловые практики были неэффективны, носили коррумпированный характер и осуществлялись без учета интересов местного населения.

Ключевые слова: мьянманско-китайские отношения, политические контакты, двусторонняя торговля, инфраструктурные проекты, восприятие местного населения, антикитайские настроения

C) Wai Yan Phyo Naing, 2020. 


\section{Introduction}

The period between 2001 to 2010 is often described as the golden time in relations between Myanmar and China. Meanwhile, the bilateral ties were based mainly on the inter-state cooperation. Therefore, Myanmar's locals were of the opinion that Beijing was the key supporter of the military junta since they had never approved of the Tatmadaw government. The article explores political relations and the bilateral trade, as well as Myanmar local's attitude towards China, and the advantages and vulnerabilities of Myanmar's position between China and other regional actors in the 2000s. In this regard, crucial questions are raised. Which issues were pivotal in shaping Myanmar's relations with China? How did the leaders create the phenomenon known as the "golden time" in China-Myanmar dialogue? Why did these relations reach the elastic limit in the perception of Myanmar's grass-root citizens? D.Steinberg and Hongwei Fun (2012) thoroughly explored Sino-Myanmar ties, and their analysis gave Western scholars revealing insights into the subjects under consideration. However, they did not specify that Myanmar had become China's close ally as the outcome of the disadvantages of the US policy to isolate Myanmar. Atsuko Mizumo (2016) examined Myanmar's dialogue with China since the early period of the military junta 1988 with valuable assessments of economic cooperation. However, this research focuses only on trade cooperation and the Chinese investments in Myanmar.

The author analyzed local sources and papers, as well as conducted interviews with local residents. This has enabled him to carry out a multi-faceted and comprehensive research on Myanmar-China relations.

\section{The Political Dimension: State-Centrism Prevailed}

On 12 December 2001, after a sixteen-year interval after the state-visit of China President Li Xiannian in 1985, President Jiang Zemin arrived in Yangon, which marked the highest point in bilateral relations between the two countries. ${ }^{1}$ The Chinese President brought a 135 member delegation and described that trip as "an important event in the history of bilateral relations, which is of significance for pushing forward the overall development of the bilateral good-neighborly friendship and cooperation in the new century. ${ }^{2}$ Revealingly, Myanmar's government released more than 200 Chinese national from jail as an arrival gift for the President's trip. ${ }^{3}$ During that visit, the two leaders agreed "to carry on their friendship (bilateral relations) from generation to generation." This visit resulted in agreements on economic and technical co- 
operation, investment promotion and protection, as well as financial allocations for infrastructure projects including hydropower plants. ${ }^{5}$

In January 2003, the Chairman of SPDC reciprocated by paying a state visit to China for the second time as head of government and head of state. ${ }^{6}$ The two leaders reached an agreement on economic, technological and public health and sports cooperation. Following that visit, the SPDC's Vice-Chairman went to Beijing in August 2003. . After a series of meetings, a Memorandum of Understanding on hydropower projects which included a loan of 200 million USD was signed. After taking office in August 2003, Prime Minister General Khin Nyunt announced the "Seven-Point Roadmap" for democratic reforms. According to Maung Aung Myoe, China's leaders supported the General Khin Nyunt since they thought he would become the next head of state and a reformer in Myanmar. ${ }^{8}$

In March 2004, Chinese Vice Premier Wu Yi visited Myanmar with a 40-member business delegation. During her journey, she met with General Khin Nyunt, and they attended the signing ceremony of 12 agreements and MOUs, including China's assistance for an international convention center in Naypyidaw. ${ }^{9}$ In July 2004, General Khin Nyunt reciprocated with a goodwill visit to Beijing, during which numerous issues in Myanmar's cooperation with China were raised and discussed. However, in October 2004 he was removed from his position and put under the house arrest as a result of intra-SPDC tensions. ${ }^{10}$ Remarkably, Beijing did not receive any prior information on forthcoming reshuffle in Myanmar's leadership. ${ }^{11}$

In November 2004, SPDC sent its new Prime Minister, Lieutenant General Soe Win to Beijing to attend China-ASEAN Business and Investment Summit, where he met with Chinese Vice-Premier Wu Yi. ${ }^{12}$ After he discussed Myanmar's domestic issues with the Vice Premier, $\mathrm{Wu}$ Yi stated that "Myanmar internal problems could only be solved by the government and people of Myanmar themselves, and that outside pressures would be unhelpful."13 On 14 February 2006, SPDC's Prime Minister travelled again to China at the invitation of Premier Wen Jiabao. He held in-depth discussions with Chinese President Hu Jintao, Premier Wen Jiabao and other Chinese top-level officials. During Soe Win's meeting with Wen Jiabao, the Chinese Premier mentioned that "China would like to jointly advance bilateral cooperation in the economic and trade area with Myanmar in the spirit of equality and mutual benefits". ${ }^{14}$ 
In October 2006, SPDC's Prime Minister General Soe Win and Chinese Premier Wen Jiabao met again on the sidelines of ChinaASEAN Commemorative Summit, marking the $15^{\text {th }}$ anniversary of establishment of Dialogue Relations between China and ASEAN. ${ }^{15}$ On 26 February 2007, Chinese State Councilor Tang Jiaxuan visited Naypyidaw and met with SPDC Chairman Senior General Than Shwe. During his meeting with the Senior General, the Chinese State Councilor advised making progress in national reconsolidation, as Myanmar's leaders had promised. ${ }^{16}$

While General Soe Win took a break from his position due to health reason, in June 2007 the SPDC acting Prime Minister General Lieutenant General Thein Sein went to Beijing and informed the Chinese leaders on the latest developments. ${ }^{17}$ Two months later, the Buddhist monks led an anti-government movement in Myanmar, so-called "Saffron Revolution" by international media. On 13 September 2007, Myanmar Foreign Minister Nyan Win visited Beijing as a special envoy of SPDC Chairman Senior General Than Shwe, explaining the intricacies of Myanmar's domestic political situation to the Chinese leaders. In his meeting with China's State Councilor, Jang Jiaxuan expressed Beijing's concern that "China, as a friendly nation to Myanmar, sincerely hoped that Myanmar could resume domestic stability in the earliest time possible". 18

On 2 May 2008, Cyclone Nargis destroyed some of Myanmar's regions, especially the Ayeyarwaddy Delta. As a result, more than 100,000 people lost their lives, and 1.5 million lost their accommodations. ${ }^{19}$ The Chinese government sent technicians for the disaster relief programs. On 8 August 2008, Prime Minister General Thein Sein met with Chinese Premier Wen Jiabao as part of the opening ceremony of the Beijing Olympics, and expressed gratitude to China's leaders for their support of Myanmar during the times of hardship. ${ }^{20}$ In April 2009, the two leaders met again on the sidelines of the Boao Forum.

The SPDC's Vice-chairman Vice Senior General Maung Aye visited to China in June 2009 and declared to Chinese Vice President Xi Jianping that "Myanmar is ready to work with China to push forward bilateral ties and to enhance the economic cooperation between two countries." ${ }^{21}$ To reciprocate, in December 2009 Vice President Xi Jinping visited Naypyidaw and attended to the signing ceremony of 16 documents, including five agreements on trade, economic matters, transport infrastructure, technical cooperation and purchase of machinery. ${ }^{22}$ On 3 June 2010, Chinese Premier Wen Jiabao visited Myanmar to celebrate the 
60th Anniversary of Sino-Myanmar diplomatic ties and met the SPDC's Chairman Senior General Than Shwe in Naypyidaw. ${ }^{23}$ During the meeting with Senior General, Premier Wen Jiabao stated that "China values friendly and good-neighborly relations with Myanmar from a strategic perspective." Myanmar's Leaders also briefed the Chinese Premier on the development of Myanmar domestic politics and preparatory work for the General Election in November 2010. ${ }^{24}$

Analyzing Sino-Myanmar ties throughout the 2000s, the assessment that the two governments enjoyed diplomatic bilateral visits and leaders' personal relationship to promote political and economic ties between two countries seems relevant. At the same time, Myanmar was under harsh economic sanctions imposed by the US and other Western countries, which forced Myanmar's military leaders to forge closer ties Beijing. Since it was nearly impossible to attract foreign capital, China also emerged as the top investor in Myanmar's economy. As Atsuko Mizumo mentioned, Myanmar became a significant recipient of Chinese assistance and distribution of Chinese foreign economic cooperation during the $2000 \mathrm{~s}^{25}$

\section{Economic and Social Ties: Top-Level Optimism and Grassroot Suspicions}

As a result of the two governments' friendly relations, the value of the Sino-Myanmar trade slightly increased again in 1999 and 2000 with 508.21million USD and 621.26 million USD respectively. ${ }^{26}$ However, the trade equilibrium between the two countries was not maintained, and the fact that in 2000 Beijing enjoyed the trade surplus of 371.62 million USD is representative. Meanwhile, the total value of trade increased nearly twofold between 1990 to 2000 from 327.62 million USD to 621.26 million USD. ${ }^{27}$ During the Chinese President Jiang Zemin's visit to Myanmar in 2001, the two countries signed a series of loans with the focus on development of Myanmar's infrastructure, including hydro-power dams. ${ }^{28}$

In this context, Beijing agreed to grant Naypyidaw a new concessional loan of 200 million USD for infrastructure needs, as well as on the allocation of 50 million USD as a supplement to the previous loan. As Atsuko Mizumo pointed out, that agreement had been the highest-ever recorded credit line in the history of Myanmar's ties with China ${ }^{29}$. According to the Chinese statistics, between 2001 and 2005 the SinoMyanmar trade increased from 354 million USD to 763 million USD. The series of discussions between SPDC's Prime Minister General Soe 
Win and China's Premier in February and October 2006 resulted in agreements to promote comprehensive economic cooperation including the energy sector, railways, as well as special economic zones. Also, China pledged to allocate 8.5 million USD and then 200 million USD low-interest loan for those projects. ${ }^{30}$ Beijing also encouraged SPDC to introduce the Special Economic Zone Law, and Myanmar's leaders drew the "Thilawa Special Industrial Zone project, simultaneously with Chinese export processing zone (EPZs). At the same time, in 2006 China's companies invested in Myanmar's hydropower projects with the amount of 281.22 million USD. At this juncture, in 2006 the Sino-Myanmar trade increased to 1459.9 million USD. ${ }^{31}$ Later on, the bilateral trade turnover markedly increased and in 2010 it accounted for 4441.7 million USD. ${ }^{32}$ Notably, Myanmar imported only for 961 million USD.

Some of China's big projects with the focus on natural resources became in the public attention spotlight in 2011. Among them, Myitsone Hydropower Dam General Project, Letpadaung Taung Copper Mine Project, Kyauk Phyu Deep Seaport and oil and gas pipeline project were the famous for the local activists and international media. All the projects were expensive. To substantiate, suffice it to mention that only the Myisone project's amount of investment reached about 20 billion USD 33. Like Myitsone, the 1.1 billion USD joint investment for Lepadaung Taung project also finalized when Chinese Premier Wen Jiabao visited Naypyidaw in March 2010.

It might seem that Sino-Myanmar relations were problem-free under the SPDC rule. At the same time, the military leaders always tried to reduce their dependence on China and develop relations with other regional powers. ${ }^{34}$ The Tatmadaw government always prioritized Myanmar's geopolitical potential. According to Maung Aung Myoe, Myanmar was "the weak link in the regional China containment policy".35 Meanwhile, at the grassroot level perceptions that China was a prominent supporter of the SPDC's regime were widespread.

Myanmar was the main destinations for Chinese migrants, especially from Yunnan Province. The cities of Upper Myanmar and Mandalay, the second-largest city of the country at that time, were growing, and Chinese migrants bought real estate paying a high price for property located in the city center. According to available estimates, from 30 to 40 percent of Mandalay populations increased due to Chinese immigration in the 1990s and 2000s. ${ }^{36}$ Nowadays, Mandalay's city center is inundated with Chinese businesses. At the same time, corruption involving Chinese migrants and local authorities was rampant. Since Myanmar's 
citizens did not support their military government, the afore-mentioned situations generated anti-Chinese sentiments. ${ }^{37}$

On the whole, an imbalance between the top-level expectations with regard to prospects for Myanmar's cooperation with China, and grassroot sentiments focusing upon day-to-day aftereffects of this cooperation, was noticeable. This factor threatened to undermine MyanmarChina dialogue making it vulnerable and prone to setbacks.

\section{Conclusion}

The analysis of Myanmar-China relations during the 2000s reveals a highly ambiguous picture which runs counter Myanmar's official rhetoric and high expectations of Myanmar's officials regarding prospects for cooperation.

Stating that Myanmar's ties with China were smooth, it is worth noting that it existed only at the government-to-government level and related to the state-supported economic projects. Business ties were fostered mainly due to positive outcomes of mutual visits made by prominent political figures.

In November 2010, the military government held general elections, first after 1990. However, as the National League for Democracy, the main opposition party, was against the elections, the military government-backed party, the Union Solidarity and Development Party (USDP) celebrated the victory. When the USDP party came into power in March 2011, Prime Minister Thein Sein of SPDC became the first President. ${ }^{38}$ Local and international researchers remarked that Myanmar's relations with China would not change significantly.

Discouragingly, however, since the Tatmadaw governments finalized all the bilateral agreements on the state-level projects in a hurry before their stepping down, Sino-Myanmar relations reached their limit in the first period of Thein Sein's administration. Meanwhile, Myanmar's people repeatedly mentioned significant Chinese investments agreed upon by the late military regime. Revealingly, President Thein Sein suspended the Myitsone Hydropower dam general project following an outbreak of public opposition. ${ }^{39}$ This case reflected the Myanmar locals' and former military generals' views on China during the Tatmadaw government rule. Grassroot citizens never supported their military regime and the army-backed USDP government, which further increased Sinophobia in the present-day Myanmar. 
${ }^{1}$ New Light of Myanmar Newspaper, 13. 12. 2001

2 Jiang's Myanmar Visit Successful: Chinese FM, Xinhua News Agency, 16 December 2001

${ }^{3}$ Tin Maung Maung Than, Myanmar And China: A Special Relationship?, ISEAS-Yusof Isak Institute, Southeast Asian Affairs, 2003, P. 196, URL:

http://www.jstor.org/stable/27913234

${ }^{4}$ Maung Aung Myoe. In The Name of Pauk-Phaw: Myanmar's China Policy Since 1948, Institute of Southeast Asian Studies, Singapore, 2011, P. 113

${ }^{5}$ Atsuko Mizumo. Economica Relations Between Myanmar and China, JICA Research Institute, Department of International Economy and Business, Faculty of Economics, Kyushu University, Japan, 2016, P. 203, URL: https://link.springer.com/chapter/10.1007/9784-431-55735-7 8.

${ }^{6}$ New Light of Myanmar Newspaper, 10. 1. 2003

${ }^{7}$ Myanmar second top leader Maung Aye Leaves on official visit to China, Global Times, 15. 6. 2009, URL: https://www.globaltimes.cn/content/437060.shtml

${ }^{8}$ Maung Aung Myoe. In The Name of Pauk-Phaw: Myanmar's China Policy Since 1948, Institute of Southeast Asian Studies, Singapore, 2011, P. 115

${ }^{9}$ Atsuko Mizumo. Economica Relations Between Myanmar and China, JICA Research Institute, Department of International Economy and Business, Faculty of Economics, Kyushu University, Japan, 2016, P. 203, URL: https://link.springer.com/chapter/10.1007/9784-431-55735-7_8.

${ }^{10}$ New Light of Myanmar Newspaper, 19. 10. 2004

${ }^{11}$ Atsuko Mizumo. Economica Relations Between Myanmar and China, JICA Research Institute, Department of International Economy and Business, Faculty of Economics, Kyushu University, Japan, 2016, P. 203, URL: https://link.springer.com/chapter/10.1007/9784-431-55735-7_8.

${ }^{12}$ Xinhua News Agency, November 3, 2004, URL:

http://www.china.org.cn/english/2004/Nov/111050.htm

${ }^{13}$ New Light of Myanmar Newspaper, 6. 11. 2004

${ }^{14}$ New Light of Myanmar Newspaper, 17. 2. 2006

${ }^{15}$ New Light of Myanmar Newspaper, 1. 11. 2006

${ }^{16}$ New Light of Myanmar Newspaper, 27. 2. 2007

${ }^{17}$ New Light of Myanmar Newspaper, 6. 6. 2007

${ }^{18}$ State Councilor Tang Jiaxua Meets with Special Envoy of SPDC Chairman of Myanmar, 13. 09. 2007, Ministry of Foreign Affairs of the People's Republic of China, URL:

https://www.fmprc.gov.cn/mfa_eng/wjb_663304/zzjg_663340/yzs_663350/gjlb_663354/2 747_663498/2749_663502/t363133.shtml

${ }^{19}$ Cyclone Nargis, Facts and Details, URL: http://factsanddetails.com/southeastasia/Myanmar/sub5_5h/entry-3139.html

${ }^{20}$ New Light of Myanmar Newspaper, 9. 8. 2008

${ }^{21}$ New Light of Myanmar Newspaper, 21. 6. 2009

${ }^{22}$ New Light of Myanmar Newspaper, 21. 12. 2009

${ }^{23}$ New Light of Myanmar Newspaper, 4. 6. 2010

${ }^{24}$ Wen Jiabao Meets with Than Shwe, Chairman of the State Peace and Development Council of Myanmar, 03. 06. 2010, URL:

https://www.fmprc.gov.cn/mfa_eng/wjb_663304/zzjg_663340/yzs_663350/gjlb_663354/2 747_663498/2749_663502/t706665.shtml

${ }^{25}$ Atsuko Mizumo. Economica Relations Between Myanmar and China, JICA Research Institute, Department of International Economy and Business, Faculty of Economics, Kyu- 
shu University, Japan, 2016, P. 201, URL: https://ink.springer.com/chapter/10.1007/9784-431-55735-7_8.

${ }^{26}$ Maung Aung Myoe. In The Name of Pauk-Phaw: Myanmar's China Policy Since 1948, Institute of Southeast Asian Studies, Singapore, 2011, P.152

${ }^{27}$ Helene Le Bail and Abel Tournier, Form Kunming to Mandalay: The New "Burma Road", Developments Along The Sino-Myanmar Border Since 1988, The Institut Francais des relations internationals, March 2010, P. 14, URL:

http://www.burmalibrary.org/docs08/IFRI_av25lebailtourniere(en).pdf

28 Atsuko Mizumo. Economica Relations Between Myanmar and China, JICA Research Institute, Department of International Economy and Business, Faculty of Economics, Kyushu University, Japan, 2016, P. 203, URL: https://link.springer.com/chapter/10.1007/9784-431-55735-7_8.

${ }^{29}$ Ibid.

${ }^{30}$ Atsuko Mizumo. Economica Relations Between Myanmar and China, JICA Research Institute, Department of International Economy and Business, Faculty of Economics, Kyushu University, Japan, 2016, P. 203, URL: https://link.springer.com/chapter/10.1007/9784-431-55735-7_8.

${ }^{31}$ Kudo Toshihiro. China's Policy Toward Myanmar: Challenges and Prospect, IDEJETRO Institute of Developing Economics-Japan External Trade Organization, 2012, P. 5 (Table.1), http://www.ide.go.jp/English/Research/Region/Asia/201209_kudo.html 32 Ibid.

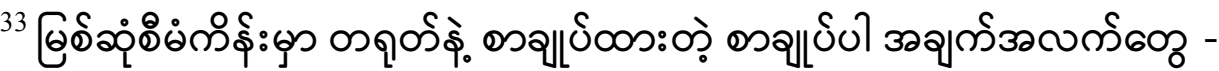

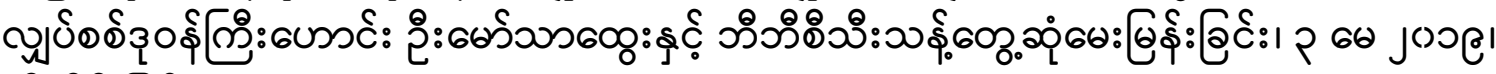

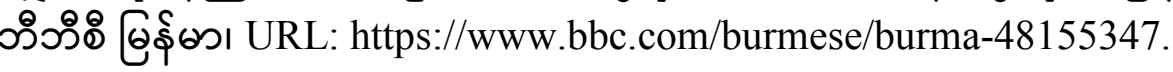

34Maung Aung Myoe, The Logic of Myanmar's China Policy, Asian Journal of Comparative Politics, 2016, P. 285, URL:

https://proxylibrary.hse.ru:2097/doi/pdf/10.1177/2057891116637476

${ }^{35}$ Ibid., P. 293

${ }^{36}$ Helene Le Bail and Abel Tournier, Form Kunming to Mandalay: The New "Burma Road", Developments Along The Sino-Myanmar Border Since 1988, The Institut Francais des relations internationals, March 2010, P. 36, URL:

http://www.burmalibrary.org/docs08/IFRI_av25lebailtourniere(en).pdf

37 Atsuko Mizumo. Economica Relations Between Myanmar and China, JICA Research Institute, Department of International Economy and Business, Faculty of Economics, Kyushu University, Japan, 2016, P. 2220, URL: https://link.springer.com/chapter/10.1007/9784-431-55735-7_8.

${ }^{38}$ Maung Aung MYOE, Myanmar's China Policy since 2011: Determinants and Directions, Journal of Current Southeast Asian Affairs, Vol. 34, No. 2, 2015, pp. 38 URL: https://journals.sub.uni-hamburg.de/giga/jsaa/article/view/872/879.html.

39 Appendix (2012), Chronology of the Myitsone Dam at the Confluence of Rivers above Myitkyina and Map of Kachin State Dams, Journal of Current Southeast Asian Affairs, Vol. 31, No. 1, pp. 150, URL: https://d-nb.info/1024416801/34.

Статья поступила в редакцию 18.11.2020, принята к публикации 30.11.2020. 